\title{
PENGARUH PERAN KEPEMIMPINAN KEPALA SEKOLAH, MOTIVASI BERPRESTASI DAN KEPUASAN KERJA TERHADAP KINERJA GURU PADA SEKOLAH DASAR DI KECAMATAN PEDES KABUPATEN KARAWANG
}

\author{
Tina Destiana Pratama \\ tinadestianap@gmail.com \\ Universitas Singaperbangsa Karawang
}

\begin{abstract}
ABSTRAK
Penelitian ini berjudul Suatu Kajian Pengaruh Kepemimpinan Kepala Sekolah, Motivasi Berprestasi dan kepuasan Kinerja terhadap Kinerja Guru di SD Kecamatan Pedes Kabupaten Karawang.

Masalah utama yang akan dikaji dalam penelitian ini adalah bahwa kinerja guru di lingkungan SD Kecamatan Pedes belum optimal. Hal ini diduga antara lain dipengaruhi oleh Kepemimpinan kepala sekolah, Motivasi Berprestasi dan Kinerja guru. Dari bahasan tersebut, peneliti sangat tertarik untuk mengadakan penelitian di SD Se-Kecamatan Pedes. Masalah yang dibahas perlu dibatasi yaitu sejauh mana pengaruh Kepemimpinan kepala sekolah, Motivasi Berprestasi dan Kepuasan Kerja terhadap kinerja guru. Responden dalam penelitian ini adalah seluruh guru di SD SeKecamatan Pedes, sebanyak 146 orang. Alat analisis data yang digunakan adalah analisis jalur.

Hasil perhitungan deskriptif menunjukan bahwa berdasarkan persepsi responden mengenai Kepemimpinan Kepala Sekolah, Motivasi Berprstasi dan Kepuasan Kinerja Guru SD Kecamatan Pedes serta Kinerja Guru berada pada kategori cukup baik. Sedangkan hasil analisis deskriptif melalui analisis jalur diperoleh nilai besarnya pengaruh langsung dan tidak langsung menunjukan bahwa pengaruh Kepemimpinan kepala sekolah secara langsung adalah sebesar 31,9\%, mengaruh tidak langsung melalui motivasi berprestasi sebesar $17.0 \%$. pengaruh tidak langsung melalui kepuasan kinerja sebesar $25.3 \%$, sehingga total pengaruh kepemimpinan kepala sekolah terhadap kinerja guru adalah sebesar 25.8\%. Pengaruh langsung motivasi berprestasi terhadap kinerja guru adalah sebesar 31,9\%, pengaruh tidak langsung kompetensi guru terhadap kinerja guru melalui motivasi kerja guru adalah sebesar $17.0 \%$ dan total pengaruh kompetensi guru terhadap kinerja guru sebesar $25.3 \%$,. Pengaruh langsung motivasi kerja guru terhadap kinerja guru adalah sebesar $31,9 \%$, pengaruh tidak langsung melalui manajerial kepala sekolah sebesar
\end{abstract}


5,18\% dan pengaruh tidak langsung melalui kompetensi guru adalah $25.8 \%$ dan total pengaruh motivasi kerja guru terhadap kinerja guru sebesar $17.0 \%$.

Hasil perhitungan Koefisien determinasi (R kuadrat) yang dinyatakan dalam persentase mengambarkan besarnya kontribusi semua variabel bebas dalam menentukan kinerja (Y) adalah sebesar 74.2\%. Sedangkan faktor lain yang tidak diteliti dan turut mempengaruhi kinerja ditunjukan oleh nilai PyC $=0.258$ atau sebesar $25.8 \%$.

Kata Kunci : Kepemimpinan Kepala Sekolah, Motivasi Berprestasi, Kepuasan Kerja , Kinerja Guru.

\section{PENDAHULUAN}

\section{A. Latar Belakang}

Pembangunan Nasional bertujuan untuk mewujudkan masyarakat yang adil dan makmur, berkeadilan sosial berdasarkan Pancasila sila ke-5 "Keadilan sosial bagi seluruh rakyat Indonesia" dan sejalan dengan Undang-Undang Dasa Negara Republik Indonesia (UUD) 1945. Pembangunan Nasional merupakan rangkaian pembangunan yang berkesinambungan dalam segala aspek kehidupan berbangsa dan bernegara. Aspek yang tidak kalah pentingnya adalah aspek pendidikan bangsa. Hal tersebut di maklumatkan dalam pembukaan UUD 1945 pada alinea ke-4 yakni :

Kemudian dari pada itu untuk membentuk suatu pemerintah negara Indonesia yang melindungi segenap bangsa indonesia dan seluruh tumpah darah Indonesia dan untuk memajukan kesejahteraan umum, mencerdaskan kehidupan bangsa dan ikut melaksanakan ketertiban dunia yang berdasarkan kemerdekaan perdamaian abadi dan keadilan sosial, maka disusunlah kemerdekaan kebangsaan Indonesia itu dalam suatu Undang-Undang Dasar negara Indonesia yang terbentuk dalam suatu susunan negara republik Indonesia yang berkedaulatan rakyat dengan berdasar kepada : Ketuhanan Yang Maha Esa, Kemanusiaan yang adil dan beradab, persatuan Indonesia, dan kerakyatan yang dipimpin oleh hikmat kebijaksanaan dalam permusyawaratan / perwakilan, serta dalam mewujudkan suatu keadilan sosial bagi seluruh rakyat Indonesia.

Pendidikan merupakan sebuah proses dan sekaligus sistem yang bermuara dan berujung pada pencapaian suatu kualitas manusia tertentu yang dianggap dan diyakini sebagai yang ideal ( Abdullah Fadjar, dalam Diki Cendana, 2012). Dalam tata kehidupan yang berkembang semakin rumit, proses dan sistem pendidikan sukar berjalan dengan mulus, karena akan terjebak dengan persoalan demi persolan yang siap menghadang lajunya proses pencapaian tujuan pendidikan.

167.

Jurnal Manajemen \& Bisnis Kreatif 
Secara sistematik, pendidikan terdiri dari berbagai komponen agar pendidikan pendidikan sebagai proses dapat berlangsung. Komponen utama setelah anak didik adalan pendidik atau guru disekolah. Peran guru di sekolah disamping strategis juga sangat menentukan karena guru adalah orang yang memegang kunci dalam keberhasilan proses pendidikan yang berlangsung. Sebagaimana termaktub dalam Undang-undang no 19 Tahun 2005 tentang standar nasional pendidikan (28:3) menyatakan "Kompetesi sebagai agen pembelajaran pada jenjang pendidikan dasar dan menengah serta pendidikan anak usia dini meliputi ; a). Kompetensi pedagogik, b). Kompetensi kepribadian, c). Kompetensi profesional, dan d). Kompetensi sosial. Oleh karena itu, diperlukan upaya-upaya untuk meningkatkan sumber daya manusia yang memungkinkan terjadinya peningkatan profesionalisme.

Undang-undang republik Indonesia Nomor 14 tahun 2005 tentang guru dan dosen menyebutkan bahwa guru adalah pendidik profesional dengan tugas utama mendidik, mengajar, membimbing, mengarahkan, melatih, menilai dan mengevaluasi peserta didik. Oleh karena itu, guru merupakan tokoh sentral dalam penyelenggaraan pendidikan karena bagaimanapun guru adalah pihak yang berinteraksi langsung dengan siswa dalam proses pembelajaran dan penentu utama dalam mewujudkan peserta didik yang berkualitas. Guru adalah yang bertanggungjawab langsung terhadap pembentukan watak peserta didik melalui pengembangan dan peningkatan kepribadian serta menanamkan nilai moral yang diinginkan dan itu harus dimulai dari pendidikan tingkat sekolah dasar karenanya guru SD harus memiliki kinerja dan disiplin yang baik. Guru harus menjadi teladan yang baik bagi peserta didiknya. Maka guru dituntut untuk memiliki kompetensi sosial dan kepribadian yang baik selain kompetensi mengajar. Untuk itu diperlukan pengelolaan tenaga pendidik dan tenaga kependidikan terutama tenaga pendidik sehingga didapatkan pendidik / guru yang memiliki kinerja yang baik sesuai dengan tuntutan dan kebutuhan masyarakat.

Undang-undang no 20 tahun 2003 tentang sistem pendidikan nasional (39:2) menyebutkan bahwa:

Pendidik merupakan tenaga profesional yang bertugas merencanakan dan melaksanakan proses pembelajaran, menilai hasil pembelajaran, melakukan pembimbingan dan pelatihan, serta melakukan penelitian dan pengabdian kepada masyarakat, terutama bagi pendidik pada perguruan tinggi.

Kunci keberhasilan dalam pengelolaan kegiatan belajar mengajar adalah kemampuan profesional guru. Guru dianggap sebagai orang yang memiliki keahlian tertentu dalam bidang pendidikan, diserahi tugas dan wewenang untung mengelola kegiatan belajar mengajar agar dapat mencapai tujuan tertentu. Keberhasilan tugas

168. 
guru dalam pengelolaan pembelajaran sangat ditentukan oleh beberapa hal, diantaranya adalah : hubungan interpersonal guru dengan siswa, adanya perbedaan individual dan kemampuan siswa, tidak adanya balikan berupa saran atau kritik untuk pengembangan kompetensi. Kompetensi profesionalnya dari teman sejawat atau guru lain, padahal apa yang sudah dilakukannya selama ini belum tentu benar. Keberhasilan guru dalam mengajar menunjukan kenaikan dalam kualitas pendidikan.

Permasalahan yang terjadi sekarang ini adalah pada lingkungan UPTD PAUD dan SD Kecamatan Pedes Kabupaten Karawang masih banyak guru yang belum menunjukan sikap dan perilaku yang kreatif dan produktif sebagai guru dalam melaksanakan tugas-tugas pembelajaran dan pendidikan di sekolah, akibatnya para guru tersebut kurang menunjukan kinerja yang tinggi dalam melaksanakan tugasnya sebagai guru dan hal ini dipengaruhi pula oleh menejemen kepemimpinan kepala sekolah yang belum efektif dalam menejemen organisasi sekolah sehingga berpengaruh terhadap kinerja mengajar guru. Kinerja guru di kecamatan pedes cenderung menurun, hal ini di tandai dengan menurunnya hasil rata-rata nilai UN mata pelajaran Indonesia sebesar 7.37 dan mata pelajaran MTK sebesar 6.2

Keberhasilan pendidikan di sekolah sangat ditentukan oleh keberhasilan kepala sekolah dalam mengelola tenaga kependidikan yang tersedia di sekolah. Kepala sekolah merupakan salah satu komponen pendidikan yang berpengaruh dalam meningkatkan kinerja guru. Kepala sekolah bertanggungjawab atas penyelenggaraan kegiatan pendidikan, administrasi sekolah, pembinaan tenaga kependidikan lainnya, dan pendayagunaan serta pemeliharaan sarana dan prasarana (Mulyasa 2007:25). Hal tersebut menjadi lebih penting sejalan dengan semakin kompleksnya tuntutan tugas kepala sekolah, yang menghendaki dukungan kinerja yang semakin efektif dan efisien

Tugas kepala sekolah dalam kaitannya dengan menejemen tenaga kependidikan di sekolah bukanlah pekerjaan yang mudah, karena tidak hanya mengusahakan tercapainya tujuan sekolah, tetapi juga tujuan pendidikan. Oleh karena itu, kepala sekolah dituntut untuk memiliki instrumen pengelolaan tenaga kependidikan seperti daftar absensi, daftar urut kepangkatan, daftar riwayat hidup, daftar riwayat pekerjaan dan kondisi tenaga kependidikan untuk membantu kelancaran pendidikan di sekolah yang dipimpinnya. Sesuai dengan ini, Mulyasa (2007:158) berpendapat dalam melaksanakan tugas dan fungsinya, jajaran pimpinan pada dinas pendidikan termasuk kepala sekolah memiliki gaya kepemimpinan masing-masing, yang sangat mempengaruhi para kinerja tenaga kependidikan dilingkungan kerjanya masingmasing 
Dengan merujuk pada rendahnya capaian pembelajaran siswa sebagai indikator kinerja guru, tentu dapat diduga tidak terlepas dari rendahnya kepala sekolah dalam menjalankan perannya, hal ini dapat terlihat dari survey pendahuluan yang dilakukan kepada 30 guru menurut 30 responden menunjukkan lemahnya peran kepemimpinan kepala sekolah khususnya dalam hal membangun komunitas pembelajaran dan mendukung prakarsa dan inovasi di kalangan guru yang menjadi bawahannya

Kegagalan dan keberhasilan sekolah banyak ditentukan oleh kepala sekolah. Karena kepala sekolah merupakan pengendali dan penentu arah yang hendak ditempuh oleh sekolah dan tujuannya. Kepemimpinan kepala sekolah merupakan faktor yang sangat penting dalam menciptakan budaya kerja guru yang akan berpengaruh terhadap kinerja mengajar guru untuk mencapai kualitas pendidikan masing-masing sekolah.

Selain faktor motivasi berprestasi, kinerja guru juga dipengaruhi oleh kepuasan kerja guru. Menurut Tumbur Hutasoit ( 2011 ), bahwa iklim kerja, kepuasan kerja dan motivasi berprestasi dapat dijadikan sebagai faktor dalam menentukan kinerja guru. Pemberian kompensasi dalam bentuk sertifikasi, oleh pemerintah tidak serta merta meningkatkan kepuasan kerja para guru, hal ini disebabkan salah satu faktor yakni keterlambatan pembayaran kompensasi yang dilakukan pemerintah mempengaruhi kinerja para guru.

\section{B. Perumusan Masalah}

Untuk mempermudah menganalisis masalah tersebut perlu dirinci kedalam perumusan masalah sebagai berikut :

1. Bagaimana Peran KepemimpinanKepala Sekolah pada Sekolah Dasar di Kecamatan Pedes Kabupaten Karawang?

2. Bagaimana motivasi berprestasi guru pada Sekolah Dasar di Kecamatan Pedes Kabupaten Karawang?

3. Bagaimana Kepuasan KerjaGuru pada Sekolah Dasar di Kecamatan Pedes Kabupaten Karawang?

4. Bagaimana Kinerja Guru pada Sekolah Dasar di Kecamatan Pedes Kabupaten Karawang ?

5. Bagaimana Pengaruh parsial Peran Kepemimpinan, motivasi berprestasi dan Kepuasan KerjaGuru terhadap Kinerja Guru pada Sekolah Dasar di Kecamatan Pedes Kabupaten Karawang?

6. Bagaimana Pengaruh simultan Peran Kepemimpinan , motivasi berprestasi dan Kepuasan KerjaGuru terhadap Kinerja Guru pada Sekolah Dasar di Kecamatan Pedes Kabupaten Karawang?

170.

Jurnal Manajemen \& Bisnis Kreatif 


\section{Tujuan Penelitian}

Penelitian ini memiliki beberapa tujuan, yaitu sebagai berikut:

1. Untuk mengetahui Peran Kepemimpinan Kepala Sekolah pada Sekolah Dasar di Kecamatan Pedes Kabupaten Karawang.

2. Untuk mengetahui motivasi berprestasi guru pada Sekolah Dasar di Kecamatan Pedes Kabupaten Karawang.

3. Untuk mengetahui Kepuasan Kerja Guru pada Sekolah Dasar di Kecamatan Pedes Kabupaten Karawang

4. Untuk mengetahui Kinerja Guru pada sekolah dasar di Kecamatan Pedes Kabupaten Karawang.

5. Untuk mengetahui Pengaruh parsial Peran Kepemimpinan, motivasi berprestasi guru terhadap Kinerja Guru pada Sekolah Dasar di Kecamatan Pedes Kabupaten Karawang

6. Untuk mengetahui Pengaruh simultan Peran Kepemimpinan, motivasi berprestasi dan Kepuasan KerjaGuru terhadap Kinerja Guru pada Sekolah Dasar di Kecamatan Pedes Kabupaten Karawang.

\section{METODEOLOGI}

Variabel bebas dalam penelitian ini adalah Peran Kepemimpinan, motivasi berprestasi. dan Kepuasan kerja . Sedangkan yang menjadi variabel terikat adalah kinerja guru.

Sifat penelitian ini adalah bersifat deskriptif dan verifikatif. Penelitian deskriptif adalah penelitian yang bertujuan untuk memperoleh deskripsi tentang ciri-ciri variabel. Sifat penelitian verifikatif pada dasarnya ingin menguji kebenaran dari suatu hipotesis yang dilaksanakan melalui pengumpulan data di lapangan. Dalam penelitian ini akan diuji apakah motivasi berprestasi. Lokus kendali dan profesionalitas berpengaruh terhadap kinerja guru. Mengingat sifat penelitian ini adalah deskriptif dan verifikatif yang dilaksanakan melalui pengumpulan data di lapangan, maka metode penelitian yang digunakan adalah metode descriptive survey dan metode explanatory survey.

Unit analisis dalam penelitian ini adalah para guru di UPTD TK SD kecamatan Pedes Kabupaten Karawang. Time horizon dalam penelitian ini adalah crossectional, di mana penelitian dilakukan dalam satu waktu secara serentak. 


\section{HASIL DAN PEMBAHASAN}

\section{A. Profil Responden}

Tabel 3.1 Jumlah Responden Berdasarkan Jenis Kelamin

\begin{tabular}{|l|l|l|l|}
\hline No & Jenis Kelamin & $\begin{array}{l}\text { Jumlah } \\
\text { (orang) }\end{array}$ & Persentase \\
\hline 1 & Laki-laki & 50 & $34,3 \%$ \\
\hline 2 & Perempuan & 96 & $65,7 \%$ \\
\hline \multicolumn{2}{|l|}{ Total } & 146 & $100 \%$ \\
\hline
\end{tabular}

Sumber : Hasil pengolahan data, 2017

Berdasarkan Tabel 1.1 diketahui bahwa responden laki-laki berjumlah sekitar $34,3 \%$ dan perempuan berjumlah $65,7 \%$.

Tabel 3.2 Jumlah Responden Berdasarkan Usia

\begin{tabular}{|l|l|l|l|}
\hline No & Usia & $\begin{array}{l}\text { Jumlah } \\
\text { (orang) }\end{array}$ & Persentase \\
\hline 1 & Dibawah 26 Tahun & 23 & $15,8 \%$ \\
\hline 2 & $26-30$ Tahun & 37 & $25,3 \%$ \\
\hline 3 & $31-35$ Tahun & 36 & $24,7 \%$ \\
\hline 4 & Diatas 36 Tahun & 50 & $34,2 \%$ \\
\hline \multicolumn{2}{|l|}{ Total } & 146 & $100 \%$ \\
\hline
\end{tabular}

Sumber : Hasil pengolahan data, 2017

Berdasarkan Tabel 1.2 diketahui bahwa responden Berdasarkan usia Dibawah 26 Tahun berjumlah sekitar 15,8 \%, 26 - 30 Tahun berjumlah 25,3\%, 31 - 35 Tahun berjumlah sekitar 24,7 \% dan Diatas 36 Tahun berjumlah 34,2 \%.

\section{B. Uji Vadalitas}

Dari hasil uji validitas variabel kepemimpinan, motivasi berprestasi, kepuasan kerja dan kinerja guru dari 146 item pertanyaan, semua item pertanyaan kuesioner dinyatakan valid.

\section{Uji Reabilitas}

Hasil Pengolahan data dengan menggunakan Software SPSS 24.0, diperoleh hasil pengujian dari seluruh variabel seperti terlihat dalam tabel sebagai berikut : 


\section{Tabel 3.3}

\section{Hasil Uji Reliabilitas}

\begin{tabular}{|l|l|l|l|l|}
\hline No & Variabel & r Hitung & r Kritis & Keterangan \\
\hline 1 & $\begin{array}{l}\text { Peran Kepemimpinan } \\
\left(\mathrm{X}_{1}\right)\end{array}$ & 0.874 & \multirow{2}{*}{0.70} & $\begin{array}{l}\text { Sangat } \\
\text { Reliabel }\end{array}$ \\
\cline { 1 - 3 } 2 & $\begin{array}{l}\text { Motivasi Berprestasi } \\
\left(\mathrm{X}_{2}\right)\end{array}$ & 0.871 & $\begin{array}{l}\text { Sangat } \\
\text { Reliabel }\end{array}$ \\
\cline { 1 - 2 } 3 & Kepuasan Kerja $\left(\mathrm{X}_{3}\right)$ & 0.898 & $\begin{array}{l}\text { Sangat } \\
\text { Reliabel }\end{array}$ \\
\cline { 1 - 2 } 3 & Kinerja Guru $(\mathrm{Y})$ & 0.890 & $\begin{array}{l}\text { Sangat } \\
\text { Reliabel }\end{array}$ \\
\hline
\end{tabular}

Sumber : Hasil pengolahan data, 2017

Tabel 1.3 memperlihatkan bahwa hasil uji reliabilitas diketahui bahwa utuk setiap variabel, (Nilai alpha cronbach 0.81 s.d. 1.00, berarti sangat reliable). Sehingga Kepemimpinan Kepala Sekolah, Motivasi Berprestasi , Kepuasan Kerja dan Kinerja Guru dinyatakan Sangat Reliabel.

\section{Uji Normalitas}

Uji normalitas digunakan untuk mengetahui apakah suatu data mengikuti sebaran normal atau tidak, untuk mengetahui apakah data tersebut mengikuti sebaran normal dapat dilakukan dengan berbagai metode, diantaranya metode Kolmogrov Smirnov dengan ketentuan apabila variabel memiliki nilai $\alpha$ hitung lebih besar dari 0,05 maka variabel tersebut terdistribusi normal.

Tabel 4.10

Hasil Uji Normalitas

\begin{tabular}{|l|l|l|l|}
\hline \multirow{2}{*}{ Variabel } & \multicolumn{2}{|l|}{ Kolmogrov - Smirnov } & \multirow{2}{*}{ Keterangan } \\
\cline { 2 - 2 } & $\begin{array}{l}\mathrm{r} \\
\text { Hitung }\end{array}$ & r Kritis & \\
\hline Peran Kepemimpinan $\left(\mathrm{X}_{1}\right)$ & 0.073 & & $\begin{array}{l}\text { Distribusi } \\
\text { Normal }\end{array}$ \\
\cline { 1 - 2 } & \multirow{2}{*}{0.05} & $\begin{array}{l}\text { Distribusi } \\
\text { Normal }\end{array}$ \\
\cline { 1 - 2 } & 0.080 & & Distribusi \\
\hline Kepuasan Kerja $\left(\mathrm{X}_{3}\right)$ & 0.069 & & \\
\hline
\end{tabular}

173. 


\begin{tabular}{|l|l|l|l|}
\hline & & & Normal \\
\cline { 1 - 1 } Kinerja Guru (Y) & 0.083 & $\begin{array}{l}\text { Distribusi } \\
\text { Normal }\end{array}$ \\
\hline
\end{tabular}

Sumber: Hasil pengolahan data, 2017

Pada tabel 4.8 diatas menunjukan bahwa semua variabel mengikuti sebaran data normal karena nilai signifikan $\alpha$ hitung semua variabel lebih dai 0.05. Variabel Peran Kepemimpinan sebesar 0.073, Motivasi Berprestasi 0.080, Kepuasan Kerja sebesar 0.069 dan Kinerja Guru 0.083, maka semua variabel dinyatakan mengikuti sebaran data normal.

\section{E. Analisis Dekriptif}

\section{1). Rekapitulasi Skor Indikator Pada Variabel Peran Kepemimpinan (XI)}

Tabel 3.5 Rekapitulasi Skor Tiap Indikator Pada Variabel Peran Kepemimpinan
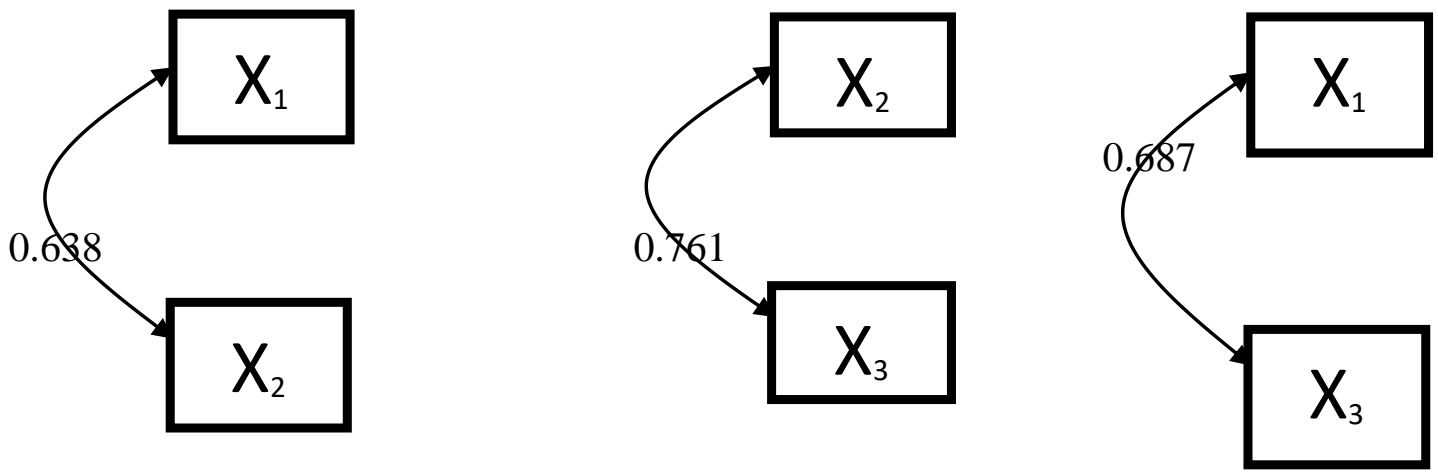

Peroleh besaran koefisien korelasi antara variabel bebas yaitu Peran Kepemimpinan $\left(\mathrm{X}_{1}\right)$ dan Motivasi Berprestasi $\left(\mathrm{X}_{2}\right)$, kemudian Motivasi Berprestasi $\left(\mathrm{X}_{2}\right)$ dan Kepuasan Kerja $\left(\mathrm{X}_{3}\right)$ sebesar 0.638 dan 0.761 dan Peran Kepemimpinan (X1) dan Kepuasan Kerja (X3) dapat dinilai sebesar sebesar 0,687 memiliki tingkat hubungan yang kuat dan searah karena nilai positif.

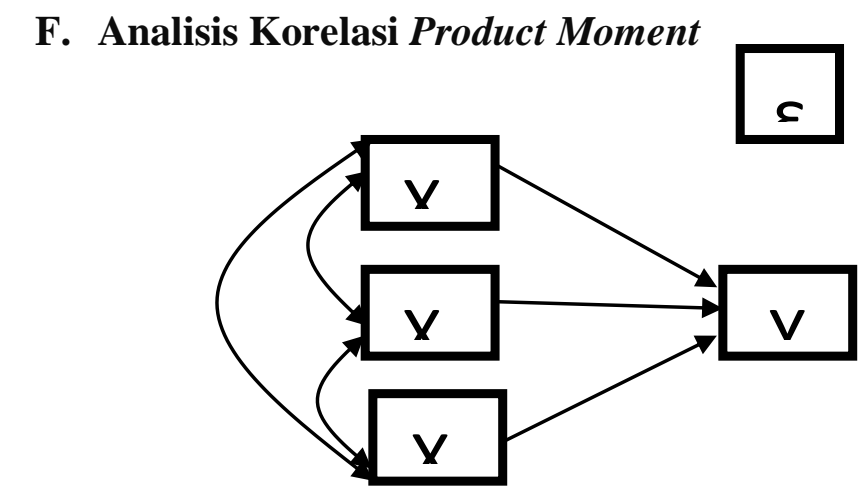

174.

Jurnal Manajemen \& Bisnis Kreatif 
Berdasarkan gambar diatas menunjukan bahwa besaran derajat positif asosiatif atau koefisien jalur variabel Peran Kepemimpinan $\left(\mathrm{X}_{1}\right)$ 0,409 lebih tinggi dari variabel Kepuasan Kerja $\left(\mathrm{X}_{3}\right)$ 0,324 dan Motivasi Berprestasi 0,230, artinya Peran Kepemimpinan $\left(\mathrm{X}_{1}\right)$ lebih berpengaruh terhadap Kinerja Guru (Y) dibandingkan dengan Kepuasan Kerja $\left(\mathrm{X}_{3}\right)$ dan Motivasi Berprestasi $\left(\mathrm{X}_{2}\right)$.

\section{G. Analisis Jalur (Path Analysis)}

Analisis jalur digunakan untuk mempelajari apakah hubungan yang terjadi disebabkan oleh pengaruh langsung dan tidak langsung dari variabel independen terhadap variabel dependen. Selain itu, analisis jalur juga mempelajari ketergantungan sejumlah variabel dalam satu model (model kausal), dan menganalisis hubungan antar variabel dari model kausal yang telah dirumuskan oleh peneliti atas dasar pertimbangan teoritis. Analisis jalur merupakan suatu metode pendekomposisian korelasi kedalam bagian-bagian yang berbeda untuk menginterpretasikan suatu pengaruh (effect).

\section{Koefisien Jalur}

\section{Coefficients $^{\mathrm{a}}$}

\begin{tabular}{|c|c|c|c|c|c|c|}
\hline \multirow[b]{2}{*}{ Model } & & \multicolumn{2}{|c|}{$\begin{array}{l}\text { Unstandardized } \\
\text { Coefficients }\end{array}$} & \multirow{2}{*}{$\begin{array}{l}\text { Standardize } \\
\text { d } \\
\text { Coefficients } \\
\text { Beta }\end{array}$} & \multirow[b]{2}{*}{$\mathrm{t}$} & \multirow[b]{2}{*}{ Sig. } \\
\hline & & B & Std. Error & & & \\
\hline \multirow[t]{4}{*}{1} & (Constant & 2,507 & 2,568 & & ,976 & ,331 \\
\hline & $\mathrm{X} 1$ & ,408 &, 060 & ,409 & 6,773 &, 000 \\
\hline & $\mathrm{X} 2$ & ,261 & ,077 &, 230 & 3,402 & ,001 \\
\hline & X3 & ,272 &, 060 &, 324 & 4,524 & ,000 \\
\hline
\end{tabular}

a. Dependent Variable: Kinerja Guru

Sumber : Hasil Pengolahan Data SPSS 23, 2017

\section{H. Analisi Verifikatif}

1. Pengaruh parsial Peran Kepemimpinan terhadap Kinerja Guru sebesar 0,319 atau 31,9\% dengan Koefisien jalur 0,409. Pengaruh parsial Motivasi Berprestasi 
terhadap Kinerja Guru sebesar 0,170 atau 17,0\% dengan Koefisien jalur 0,230. Pengaruh parsial Kepuasan Kerja terhadap Kinerja Guru sebesar 0,253 atau 25,3\% dengan Koefisien jalur 0,324. Peran Kepemimpinan memiliki nilai koefisien jalur lebih tinggi dibandingkan dengan Motivasi Berprestasi dan Kepuasan Kerja maka dapat dinyatakan bahwa variabel Peran Kepemimpinan lebih banyak memberikan kontribusi terhadap Kinerja Guru. Hal ini disebabkan karena para guru lebih melihat peran kepemimpinan kepala sekolah dibandingkan dengan kepuasan kerja dan motivasi berprestasi, sehingga ketika peran kepemimpinan baik maka kepuasan kerja dan motivasi berprestasi akan baik pula.

2. Pengaruh simultan Kepemimpinan Kepala Sekolah, Motivasi Berprestasi dan Kepuasan Kerja terhadap KInerja Guru, dengan kriteria uji Sig. $(0,000)>\alpha(0,05)$ dan $f_{\text {hitung }}(136,284)>f_{\text {tabel }}(2.43)$, artinya $H_{o}$ ditolak. Total pengaruh yang disebabkan Peran Kepemimpinan $\left(\mathrm{X}_{1}\right)$, Motivasi Berprestasi $\left(\mathrm{X}_{2}\right)$ dan Kepuasan Kerja $\left(\mathrm{X}_{3}\right)$ terhadap Kinerja Guru $(\mathrm{Y})$ yaitu sebesar 0,742 atau 74,2\% adapun pengaruh variabel lain diluar model adalah sebesar 0,258 atau $25,8 \%$.

\section{KESIMPULAN}

Berdasarkan hasil penelitian, pengumpulan data dan pembahasan yang dilakukan peneliti pada Sekolah Dasar se Kecamatan Pedes Karawang maka dapat di ambil kesimpulan sebagai berikut :

1. Kinerja Guru Guru pada Sekolah Dasar se Kecamatan Pedes Karawang sudah baik, karena indikator yang diteliti dengan total skor sebesar 9.565 dan nilai ratarata yaitu 531,4 yang berada pada rentang skala 495,5-612,7 berada pada kriteria setuju.

2. Peran Kepemimpinan Kepala Sekolah pada Sekolah Dasar se Kecamatan Pedes Karawang sudah baik, karena Indikator yang diteliti dengan total skor sebesar 8.337 dan nilai rata-rata yaitu 521,1, yang pada rentang skala 495,5-612,7 berada pada kriteria setuju.

3. Motivasi berprestasi pada Sekolah Dasar se Kecamatan Pedes Karawang yang diberikan kepada Guru sudah baik, karena indikator yang diteliti dengan total skor sebesar 6707 dan nilai rata-rata yaitu 515,9 yang berada pada rentang skala 495,5-612,7.

4. Kepuasan Kerja guru pada Sekolah Dasar se Kecamatan Pedes Karawang sudah baik karena indikator yang diteliti dinyatakan setuju oleh responden dengan total skor 9.802 dengan rata-rata 515,8, yang berada pada rentang skala 495,5-612,7.

5. Terdapat pengaruh parsial antara Kepemimpinan Kepala Sekolah terhadap Kinerja Guru sebesar 31,9\%. hal ini mendukung penelitian Nurjanah (2008), Ridwan Abdul Karim (2005), Rani Mariam (2009). Terdapat pengaruh parsial antara Motivasi Berprestasi terhadap Kinerja Guru sebesar 17\%. Hal ini 
mendukung penelitian Tri Gunarsih (2005). Terdapat pengaruh parsial Kepuasan Kerja Terhadap Kinerja Guru sebesar 25,3\%. Hal ini mendukung penelitian yang telah dilakukan oleh Rani Mariam (2009).

6. Peran Kepemimpinan Kepala Sekolah, Motivasi Berprestasi dan Kepuasan Kerjasecara simultan berpengaruh positif dan signifikan terhadap Kinerja Guru. Total pengaruh yang disebabkan Kepemimpinan Kepala Sekolah, Motivasi dan Kepuasan Kerja terhadap Kinerja Guru yaitu sebesar 74,2\% adapun pengaruh variabel lain diluar model adalah sebesar 25,8\%. Hal ini mendukung penelitian Ridwan Abdul karim (2005) dan Nurjanah (2008).

\section{DAFTAR PUSTAKA}

\section{Sumber Buku dan Jurnal :}

A.M, Sardiman. 2010. Interaksi dan Motivasi Belajar Mengajar. Jakarta: Rajawali Pers.

Ahmad Mudzakir dan Joko Sutrisno. 1997. Psikologi Pendidikan. Bandung : Pustaka Setia.

Arikunto, Suharsimi dkk. 2006. Penelitian Tindakan Kelas. Jakarta : Bumi Aksara.

Arikunto, Suharsimi.2006. Prosedur penelitian suatu pendekatan praktek, Cetakan Ketigabelas.Jakarta: PT.Rineka Cipta.

Aritonang, Keke T. 2008. "Minat dan Motivasi dalam Meningkatkan Hasil Belajar Siswa”. Jurnal Pendidikan Penabur, 7(10): 11-21.

Bambang Riyanto. 2010. Dasar-Dasar Pembelanjaan Perusahaan, ed. 4, BPFEYOGYAKARTA.

Dalyono, M. 2009. Psikologi Pendidikan. Jakarta: Rineka Cipta.

Darsono, Max. 2000. BelajarPembelajaran. Semarang. IKIP : Semarang Press.

Engkoswara. 2010. Paradigman Manajemen Pendidikan. Bandung : Yayasan Amal Keluarga.

Hambalik Oesman. 2001. Proses Belajar Mengajar. Jakarta : Balai Pustaka.

Hambalik Oesman. 2006. Proses Belajar Mengajar. Bandung : Bumi Angkasa. 
Hamzah, Moh dan Ismail. 2009. "Pengaruh Lingkungan dan Motivasi Belajar Siswa terhadap Hasil Belajar Matematika Siswa di Kejar Paket C PKBM Sultan Agung Kesambi Kota Cirebon”. Jurnal EduMa, 1(2): 101-112.

Suranto. 2015. Pengaruh Motivasi, Suasana Lingkungan dan Sarana Prasarana Belajar Terhadap Prestasi Belajar (Studi Kasus Pada SMA Khusus Putri SMA Islam Diponegoro Surakarta). Jurnal Pendidikan Ilmu Sosial. Vol 25, No.2 
